\title{
Evaluation of Dry Land Chickpea Production during the Last Ten Years (2010-2019) in Center of Badghis Province, Afghanistan
}

\section{Rahimi AG*}

Teaching Assistant of Agronomy Department, Agriculture Faculty, Badghis Higher Education Institution, Afghanistan

*Corresponding author: Abdul Ghani Rahimi, Teaching Assistant of Agronomy Department, Agriculture Faculty, Badghis Higher Education Institution, Afghanistan, +93(0)798315051; Email: abdulghani.rahimi14@gmail.com

\section{Editorial \\ Volume 4 Issue 5}

Received Date: August 06, 2020

Published Date: August 13, 2020

DOI: $10.23880 /$ jenr-16000209

\section{Abstract}

Chickpea is an annual herbaceous plant with the scientific name of Cicer arietinum L. belonging to the fabaceae family and is one of the hardiest plants that can grow well in any environmental conditions. This research was conducted in 2020. A questionnaire was used to assess the production of chickpea during the last ten years (2010-2019) in the center of Badghis Province, which statistical population consists of all farmers in the center of Badghis Province, including 50 people. Samples were randomly selected, and data was analyzed through Excel program. The results show that $66 \%$ of the people in this district are engaged in agriculture and more than $30 \%$ of their lands are under chickpea cultivation. The highest area under cultivation of chickpeas in Badghis Province was in 2011 with 326 hectares and the lowest area under cultivation was in 2013 with 198 hectares. The highest increase in production of chickpeas in the center of Badghis Province in 2012 was with 410 tons and the lowest increase in production of chickpeas was in 2018 with zero production. Also, the average yield of chickpeas in center of Badghis Province is between 2 to 5.2 tons per hectare. As a result, the production of chickpeas in this district during the last ten years has been relatively weak.

Keywords: Chickpea; Badghis Province; Total Production; Average Yield

\section{Preface}

Chickpea belongs to the fabaceae family and its ripe and dried seeds have a high nutritional value and about $90 \%$ of the area under cultivation of this plant in the world is in the form of rain feed and $10 \%$ of it is cultivated in the form of water. More than $90 \%$ of this plant is cultivated in India and Pakistan. This valuable plant has been cultivated all over Afghanistan and is currently cultivated in remote areas whereby the farmers can get good financial benefits. One of the important characteristics of chickpeas is the stabilization of atmospheric nitrogen in the soil, which makes the soil fertile for subsequent crops and is also important because of breaking the life cycle of grain diseases and pests [1]. The cultivated area of chickpea in the world is about 11 million hectares and Iran with a cultivated area of about 700 thousand hectares is ranked fourth in the world after India, Pakistan and Turkey [2]. Chickpeas are an important source of plant protein and one of the legumes that play a major role in the human diet [3]. Chickpea is a legume that due to the nitrogen fixation of the soil, the ability to grow in warm regions and has many benefits in rotation with cereals has an important role in crop rotation and improvement of agricultural lands. Chickpea is an annual and long day plant and the major geographical areas of chickpea cultivation in the world are the Indian subcontinent, West Asia, North Africa, Ethiopia and the highlands of East Africa, USA and Australia and chickpea production areas in West Asia including the highlands of West Asia. (Northern Afghanistan, Iran and Turkey) and the lowlands of West Asia [4]. Badghis Province is one of the northwestern provinces of the country, the center of which is Qala-e-Naw. Badghis borders Herat province to the west, Faryab Province to the east, Turkmenistan to the north and Ghor Province to the south. The province has an area of 


\section{Journal of Ecology and Natural Resources}

23,000 square kilometers with six districts. The population of the province in 2017 was estimated at 512,518 people and most of the people of Badghis are farmers. The economy of the people of this province is mainly based on agricultural products. Its agriculture is in the form of Rain feed and less technical and modern tools and equipment are used in it. Its agricultural products include: wheat, barley, corn, chickpea, cumin, sesame, melon, watermelon, etc.

The purpose of this study is to investigate the production of chickpeas during the last ten years (2010-2019) in center of Badghis Province, Afghanistan.

\section{References}

1. Ahlawat I, Ali M, Shivkumar B (2003) Cropping systems research in chickpea.Chickpea research in India
(EdsMasood Ali, Shiv Kumar and NB Singh). Indian Institute of Pulses Research, Kanpur, India, 113-119.

2. Sabaghpour SH, Koumar J, Rao TN (2006) Inhertance of number of pods per peduncle and its effect on other characters in chickpea (Cicer arietinum L.). Agric Sci Natur Resour 13(3): 21-28.

3. Zaidi A Khan, Amil MD (2003) Interactive effect of rhizotrophic microorganisms on yield and nutrient uptake of chickpea (Cicer arietinum L.). European Journal of Agronomy 19(1): 15-21.

4. Fallah S (2008) Effect of planting date and plant density on yield and yield component in chickpea genotype (Cicer arietinum L.) in dry condition of Khorran Abad. J Sci Techno Agric Natur Res 12(45): 123-135. 